\title{
Tarımda Alternatif Kamusallığın Olanakları: İzmir Tire Süt Kooperatifi Örneği
}

\author{
Uygar Dursun Yıldırım*
}

\begin{abstract}
Özet
Son yıllarda tarım sektörü küçük üreticiliğin çözülmesi, işsizliğin artışı, gıda krizleri, güvencesiz çalışma biçimlerinin yaygınlaşması gibi çok sayıda sorunla gündeme gelmektedir. Çalışmada toplumda "demode" bir örgütlenme modeli olarak görülen kooperatiflerin, tarımda yaşanan sorunlar karşısında ne tip çözümler ve imkânlar sağlayabileceği tartışılmaktadır. Bu çerçevede İzmir Tire'de süt sektöründe faaliyet gösteren Tire Süt Kooperatifi ve bu kooperatifin İzmir Büyükşehir Belediyesiyle işbirliği içinde yürüttüğü faaliyetler odak noktası olarak seçilmiştir. Çalışmada kooperatif ve belediye arasında yatay ilişkiler temelinde kurulan işbirliğinin tarımda yönetim, üretim, piyasa, gıda ve dağıtım boyutlarıyla ne tür olanaklar ve farklılıklar taşıdığı sorularının alternatif kamusallık kavramı etrafında incelenmesi amaçlanmaktadır.
\end{abstract}

Anahtar sözcükler: Kooperatifler, alternatif kamusallık, küçük üreticiler, g1da güvenliği, Tire

\section{Abstract \\ Possibilities of Alternative Publicity in Agriculture: The Case of Izmir Tire Milk Cooperative}

In recent years, the agricultural sector is encountering frequent problems such as dissolution of small producers, increase of unemployment, food crisis, and spread of precarious employment. The study discusses that what kind of solutions might be offered for the challenges in agriculture by cooperatives, which are regarded as "outdated" organization form by the society. In this framework Tire Milk Cooperative which operates in the milk sector in Tire, İzmir and its activities carried out in cooperation with Izmir Metropolitan Municipality are chosen as the focal point. The study aims to examine the questions of what potentiality and differences comprised in conjunction with alternative publicity concept in context of management, production, market, food and distribution aspects of agriculture with regards to cooperation formed between the cooperative and municipality on the basis of horizontal relations.

Keywords: Cooperatives, alternative publicity, small producers, food safety, Tire

\section{Giriş}

Gündelik yaşamı oluşturan bütün alanların AVM'ler ve reklamların ışıltılı dünyası tarafından hızlıca işgal edildiği, sanal alışverişin yarattığı cazibenin giderek yaygınlaştığı, giysilerin Çin ve Bangladeş’ten, elmanın Şili'den geldiği bir dönemden geçmekteyiz. İçinde bulunduğumuz dönemde gündelik hayat birçok yönüyle daha önce hiç olmadığı kadar küresel ekonominin parçası haline gelmiştir. Aynı zamanda çokuluslu ya da yerli şirketler ve bankalar aracılığıyla yürütülen para, meta hareketlerinin kredi kartları ve "online" para hareketleri aracılığıyla yaşamın bütün alanlarını kontrol altına aldı̆̆ı ve toplum genelinde yoğun bir finansallaşma ve borçlanma eğilimini gündeme getirdiği bir süreç

* Mimar Sinan Güzel Sanatlar Üniversitesi, Şehir ve Bölge Planlama Bölümü 
yaşıyoruz. Güvencesizleşme ve geleceğe yönelik artan risk ve belirsizliklerin toplumun geniş kesimlerini yoğun bir şekilde etkilediği bu süreç son 20 yılın Türkiye'sini önceki dönemlerden büyük ölçüde farklılaştırmaktadır. Yaşanan hızlı dönüşümün tarım ayağına baktığımızda, küçük üreticilerin giderek kendi toprağ1 ve ürünleri üzerindeki kontrol ve denetimi yitirdiği, bunun yerine bütün kurum, aktör ve yasal düzenekleriyle serbest piyasa işleyişinin üretim ve gıda süreçlerini belirlediği yeni bir sürece girildiğini görüyoruz. ${ }^{1}$

Türkiye'de 1930'lu yıllardan itibaren tarımdaki ağırlıklı kesim olan küçük köylülüğü korumak ve desteklemek milli ekonominin gelişmesi ve kalkınma için gerekli olan tarımsal fazlanın sağlanmasında büyük önem taşıyordu. Hatta Osmanlı İmparatorluğu'nun son dönemlerine kadar gidersek devletin, sipahiler ve kadılar vasıtasıyla reayanın toprağını ve emeğini, bu toprakları özel mülkiyete dönüştürmeye, köylüleri de bu topraklarda iş̧̧i, ortakçı ya da serf konumuna düşürmeye kalkışabilecek üçüncü şahıslara karşı özenle korumaya yönelik müdahalelerde bulunduğunu görürüz. ${ }^{2}$ Cumhuriyetin kuruluş yılllarında ve 1960'l1 y1llardan itibaren devletin oluşturduğu kurumsal, yasal düzeneklerle küçük köylü kesiminin üretken gücünün artırılması, bu kesimin ulusal pazarla eklemlenmesi ve hatta tüccar, tefeci gruplar karşısında varlığını sürdürebilmesi gibi hedeflerle kapsamlı bir koruma ve destekleme programı yürütülmüştür. Özellikle devletin öncülüğünde kurulan Tariş, Çukobirlik, Fiskobirlik, Toprak Mahsulleri Ofisi, Çaykur gibi kooperatif ve kuruluşlarla yürütülen girdi, kredi ve ürün piyasalarında sürdürülen destekleyici ve korumacı düzenlemeler sayesinde küçük köylülüğün geniş kesimleri piyasa ilişkileriyle başarıyla eklemlenebilmiştir. Ancak 1980'li yıllardan itibaren özellikle 2000'li yılların başında yaşanan ekonomik krizlerle birlikte devletin tarıma yönelik politika ve uygulamalarında büyük yapısal dönüşümler yaşanmış; aile emeğiyle üretim yapan üreticiler için risk ve güvencesizliklerin arttığ1 yeni bir döneme girilmiştir.

Dışa açık sermaye birikimi rejiminin gereklilikleri doğrultusunda tarımın daha yüksek bir verimlilik ve rekabet temelinde yeniden yapılandırılması ayrıca küresel pazarlarla bütünleşmenin önündeki engellerin kaldırılması yeni dönemin en temel özellikleri haline gelmiştir. Avrupa Birliği'ne giriş süreci, Dünya Ticaret Örgütü'yle yapılan anlaşmalar, IMF ve Dünya Bankası tarafından verilen krediler karşıllğında zorunlu tutulan düzenlemeler dünyada ve Türkiye'de tarımın neoliberal paradigma çerçevesinde yeniden yapılandırılmasında önemli rol oynamıştır. ${ }^{3}$ Yeniden yapılanma sürecinin en önemli adımlarından biri, 2001 yılında Dünya Bankası projesi olan Tarım Reformu Uygulama Projesi kapsamında Türkiye'de merkezi otorite destekli kooperatifler ve kuruluşların özerkleştirilmesidir. Bu çerçevede tarımda küçük üreticiler lehine piyasayı düzenleyen kooperatiflerin devlet destekli kredilerden yararlanmaları, merkezi bütçeden kooperatiflere kaynak aktarılması gibi uygulamalara son verilmiştir. ${ }^{4}$

1 Çalışmada küçük üreticiler, küçük meta üreticileri, küçük işletmeler gibi kavramlar Korkut Boratav'ın tanımladığı içerikle kullanılmıştır. Bu tanıma göre küçük üreticiler tüccar, tefeci ve sanayi sermayesiyle ilişkileri içinde üretim araçlarına esas itibarıyla sahip olmakla birlikte, aile emeğiyle kısmen veya piyasa için, fakat tüketim amacıyla (birikim yapmadan) üretimde bulunan bir kesimdir. Bkz. Korkut Boratav, Tarımsal Yapılar ve Kapitalizm (Ankara: İmge Kitabevi, 2004), 52.

2 Halil İnalcık, “Çiftliklerin Doğuşu: Devlet, Toprak Sahipleri ve Kiracılar”, Osmanlı Toprak Mülkiyeti ve Ticari Tarım içinde, der. Çağlar Keyder ve Faruk Tabak (İstanbul: Tarih Vakfı Yurt Yayınları, 2010), 16.

3 Zülküf Aydın, "Neo-Liberal Transformation of Turkish Agriculture", Journal of Agrarian Change 10, no. 2 (2010): 149-187.

4 Tarım Satış Kooperatiflerinin tasfiyesi sürecine ilişkin ayrıntılı bilgi için bkz. Necdet Oral, der., Türkiye'de Tarımın Ekonomi-Politiği 1923-2013 (Ankara: Notabene Yayınları, 2013). 
Girdi, kredi ve ürün piyasalarında desteklemeler yapan kooperatifler tasfiye edilirken sermayenin çeşitli fraksiyonları, Tarım Bakanlığı ve çeşitli üst kurullar üretim, gıda ve piyasanın yeniden düzenlenmesinde öne çıkan aktörler haline gelmişlerdir. Özellikle uluslararası sermayenin ve süpermarketlerin tarımda ve gıda sanayinde rolünün ve etkisinin önemli ölçüde artması yeniden yapılanma döneminin büyük sonuçlar doğuran en önemli boyutudur. ${ }^{5}$ Uluslararası sermaye yanında tüccar, tefeci, banka ve marketlerden oluşan geniş bir sermaye grubuyla küçük üreticilerin eşitsiz bir piyasa ortamında karşı karşıya geldiği bu sürecin Türkiye'nin farklı bölgelerinde yer alan küçük üreticiler üzerinde finansal darboğazlar, üretimden çekilme, mülksüzleşme ve işçileşme gibi çok yönlü olumsuz etkileri olmuştur. ${ }^{6}$ Türkiye tarımında ağırlıklı işletme tipi olan aile emeğine dayalı küçük üreticiliğin uğradığı kayıplar verilere de yansımış; 2000'li yılların başından 2012 yılına kadar yedi milyona yakın büyük bir nüfus kitlesi kırsal alanları terk ettiği gibi, 2000-2016 yılları arasında tarımda çalışan yaklaşık iki milyon kişi üretimden çekilmiştir.7

Tarımda çokuluslu ve yerli sermaye gruplarının etkinliğinin artması sürecinde üretimin rekabet baskısı ve yüksek verimlilik temelinde yeniden organize edilmesinin bir diğer önemli boyutu da küçük üreticilerin fenni gübre, hormon, tarımsal ilaçlar gibi kimyevi girdiler üreten sermaye gruplarına artan bağımlılığıdır. Daha fazla kimyasal girdiyle üretim yapılması, küçük üreticilerin bu girdileri üreten firmalara artan iktisadi bağımlılığını doğurdu. Bu durum ayrıca gıda güvenliği sorunlarını da artırarak kentsel nüfusu halk sağlığı; toprak ve suyun kirlenmesiyle doğayı da artan tahribatlar boyutuyla etkilemektedir. Kısacası sermayenin tarımda artan hâkimiyeti sadece küçük üreticiler ve mevsimlik işçiler gibi grupları değil bütün kentsel nüfusu ve doğayı etkileyen, kapsamlı tahribatlar yaratan bir süreçtir.

Sermayenin artan kontrol ve hâkimiyeti karşısında çok sayıda korumasız ve güvencesiz küçük üreticinin kooperatif tipi örgütlenmeler aracılığıyla birlik oluşturması ve üretim, gıda ve pazarlama süreçlerinde birlik olmaktan gelen güçleriyle düzenleyici rol üstlenmeleri bir ölüm kalım meselesi haline gelmiştir.

Tarım ve gıdanın sermayenin organize ettiği meta ilişkileri alanında düzenlenmesinin beraberinde getirdiği sorunlar son yıllarda Türkiye'de toplum genelinde yeni arayışları da gündeme getirmektedir. Dernekler, kooperatifler, topluluk destekli tarım grupları, yerel yönetimler, çiftçi sendikaları ve tohum takas ağları gibi oldukça çeşitlilik gösteren örgütlenmeler tarımda üretim, gıda ve tohum dağıtımı süreçlerinde alternatif modeller oluşturmaya çalışmaktadırlar. ${ }^{8} \mathrm{Bu}$ alternatiflerde üzerinde en fazla durulan örgütlenme modeli olan kooperatiflerin Türkiye'de Osmanlı'nın son dönemlerine kadar uzanan köklü bir geçmişi vardır. Ancak 2010 verilerine göre Türkiye'de konut, tarım, su ürünleri, taşımacılık gibi farklı alanlarda örgütlenmiş yaklaşık 84 bin kooperatif bulunmakta ve bunun sadece 13 bin gibi düşük bir miktarı tarım alanında örgütlenen

5 Çağlar Keyder ve Zafer Yenal, “Türkiye'de Tarım ve Gıda Üretiminin Yeniden Yapılanması ve Uluslararasılaşması", Bildiğimiz Tarımın Sonu: Küresel İktidar ve Köylülük içinde (İstanbul: İletişim Yayınları, 2013), 116.

6 Son dönemde tarımda mülksüzleşme ve işçileşme süreçlerinin mevsimlik işçiler özelinde ele alındığı bir çalışma için bkz. Uygar Dursun Yıldırım, Türkiye Tarımında Yapısal Dönüşüm ve Mevsimlik Tarım İşçileri: Sakarya Örneği (İstanbul: Sav Yayınları, 2015).

7 TÜİK'in İnternet sitesinde yer alan Hane Halkı İşgücü İstatistikleri, Genel Nüfus Sayımları ve Adrese Dayalı Kayıt Sistemi Verileri için bkz. http://www.tuik.gov.tr.

8 Fatih Özden, “Doğadan Tüketiciye Tarımda Kapitalist Tahakkümün Kimi Görünümleri, Yabancılaşma ve Alternatifler Üzerine", Praksis 43 (2017): 757. 
kooperatiflerden oluşmaktadır. ${ }^{9}$ Ayrıca Türkiye'de uzun yıllar boyunca merkezi otoritenin kontrolüne ve bütçe desteğine bağımlı kalması kooperatiflerin tabandan ve yerelden örgütlenen özerk yapılar olmasının önüne geçmiştir. Ayrıca siyasi yandaşlık, patronaj ilişkileri ve rant kavgasının yönetimlerde yerleşik hale gelmesi kooperatifleri giderek pasifize ettiği gibi kamuoyunda da itibar kaybına ve kooperatifleşme bilinci ve deneyimlerinin yaygınlaşmasına engel olmuştur. ${ }^{10}$

Bütün olumsuz deneyim birikimi ve kamuoyundaki önyargılara rağmen tarımda küçük üreticilerin öz örgütlülüğüne dayanan, yerel yönetimlerle desteklenen kooperatiflerin en yaygın olduğu illerden biri İzmir'dir. İzmir ve çevresindeki tarımsal alanlar Osmanlı́nın son dönemlerinden bu yana küçük köylülüğün kapitalizmle eklemlendiği önde gelen bölgelerden biri olduğu gibi aynı zamanda burada oldukça köklü ve zengin bir kooperatifleşme geleneği de bugüne kadar devam etmiştir. İzmir çevresinde kalan kırsal mekânlar tarımda üretim, istihdam, göç ve gıda boyutlarıyla yaşanan krize alternatif üretme olanakları taşıyan, sürece küçük üreticiler ve tüketiciler lehine müdahalelerde bulunabilen başarılı kooperatifleşme deneyimleriyle belirli özgünlüklere sahiptir.

Çalışmada bu deneyimlerden biri olan, hayvancılık ve süt üretiminin yoğun olarak yapıldığı İzmir Tire'de faaliyet gösteren Tire Süt Kooperatifi üzerinde durulacaktır. 2014 yılı verilerine göre 310 tarımsal amaçlı kooperatif bulunan İzmir'de, süt ve süt ürünleri sektöründe faaliyet gösteren kooperatiflerden biri de Tire Süt Kooperatifi'dir. ${ }^{11}$ Tire Süt Kooperatifi, süt sektöründe bir üst kurul olarak hareket eden Ulusal Süt Konseyi, endüstriyel süt üreten ve işleyen büyük firmalar ve Tarım Bakanlığı gibi aktörlerin daha yüksek kâr ve rekabet temelinde etkili olduğu bir piyasada küçük üretici ve kentsel tüketici odaklı alternatif bir model oluşturmaya çalışmaktadır. Bu kooperatifleşme deneyiminde küçük üreticiler, İzmir Büyükşehir Belediyesi ve tüketiciler gibi farklı aktörler arasında, hiyerarşik olmayan bir bütünleşme süreci içinde süt sektöründe alternatif bir yönetim, üretim, dağıtım ve tüketim modeli oluşturulması amaçlanmaktadır. Çalışmada "alternatif kamusallık" kavramı çerçevesinde ele alınan bu modelin üreticiler ve tüketiciler açısından ne tür imkânlar sağladığı, bu model içinde yer alan aktörlerin yönetsel süreçler, piyasa, fiyatlar ve gıda güvenliği boyutlarıla ne tür müdahalelerde bulunabildiği gibi sorulara yanıtlar aranacaktır. Bu çerçevede meta ilişkileri içinde düzenlenen süt ürünleri piyasasında kooperatif birlikleri tarzı örgütlenmelerin sağladığı imkânları ve taşıdığı sınırlılıkları tartışmak tarımın geleceği üzerine öngörülerde bulunmak ve alternatif üretebilmek açısından büyük önem taşımaktadır.

\section{Metodoloji}

Mart 2017'de Tire Süt Kooperatifi yöneticileri, İzmir Büyükşehir Belediyesi yetkilileri, uzmanlar ve süt üreticiliği yapan kooperatif yönetici ve ortaklarından oluşan yaklaşık 10 kişiyle derinlemesine görüşmeler yapılmıştır. Yapılan saha araştırmasında şirketlerin hâkimiyet kurmaya çalıştığı süt piyasasında küçük

9 T.C. Gümrük ve Ticaret Bakanlığı Kooperatifçilik Genel Müdürlüğü, “Türkiye Kooperatifçilik Stratejisi ve Eylem Planı 2012-2016", http://www.gtb.gov.tr.

10 Ergül Ballı, "Türkiye'de Tarımsal Kooperatifçiliğin Gelişimi ve Fiskobirlik: Tarihsel Bir Değerlendirme", Türkiye Cumhuriyeti'nin Ekonomik ve Sosyal Tarihi Uluslararası Sempozyumu'nda sunulan bildiri, Atatürk Araştırma Merkezi, İzmir, 26-28 Kasım 2015.

11 İlhan Tekeli, İzmir İli/Kenti İçin Bir Tarımsal Gelişme ve Yerleşme Stratejisi (İzmir: İzmir Akdeniz Akademisi, 2017), 163-64. 
üreticiler, kooperatif ve belediye arasındaki ilişkilerin niteliğini anlamaya yönelik sorular sorulmuştur. Endüstriyel girdi ve süt üretimi yapan firmaların güçlü olduğu bir piyasada kooperatifin üretim ve piyasanın düzenlenmesinde ne tip müdahalelerde bulunabildiği, bunların üreticiler ve tüketiciler üzerinde ne tip avantajlar yarattı̆̆ı gibi sorulara yanıt aranmaya çalışılmıştır. Çalışmada öncelikle dünyada ve Türkiye'de farklı tarihsel süreçlerde ortaya çıkan kooperatifleşme tartışmaları ve deneyimleri, teorik ve politik boyutlarıyla özetlenerek ele alınmıştır. Daha sonra saha araştırmasından elde edilen veriler, kooperatif ve belediye arasında üretilen alternatif kamusallığın çeşitli yönleri olarak ele alınmıştır.

\section{Kooperatiflere Dair Çeşitli Tanım, Tartışma ve Yaklaşımlar}

İşbirliği, beraber çalışma, güven ilkelerine dayalı olarak kurulan kooperatifler, kapitalist gelişme süreciyle birlikte gelen toplumsal sorunların su yüzüne çıtığ1 19. yüzyıldan itibaren gündeme gelmeye başlamıştır. Başlangıcından itibaren kooperatifçilik çoğu zaman kapitalizm karşısında aşağıdan yukarıya bir seçenek oluşturmanın, burjuva bireyselciliğinin yerini ortaklaşan ve toplumsal dayanışma üzerinde yükselen bir toplumun almasının yolu olarak görülmüştür. ${ }^{12}$ Çeşitli iktisadi görüşler ve siyasal tercihlerle doğrudan ilişkili olarak farklı bakış açılarının doğması herkesin üzerinde uzlaştığı bir kooperatif tanımı yapmayı zorlaştırmaktadır. Kooperatifler üzerine yapılan çok sayıda tanım ve tartışma bulunmasına rağmen biz burada sadece kapsayıcı olan ve temel özelliklerin altını çizen bir tanımı aktarmakla yetineceğiz.

Sermayenin değil insanların birleşmesinden doğan, zenginleşmek yerine iktisadi zorlukların aşılması için bir araya gelinen, kâr aramanın şahsi bir iktisadi iş haline gelmediği, katılımın serbest irade beyanına dayandığı, müşterek teşebbüsün müşterek çalışmaya dayandığı teşekküller kooperatif tanımı içinde yer almaktadır. ${ }^{13}$ Satın alma, kredi, taşımacılık, tarım ve konut tedariki gibi oldukça farklı faaliyet alanlarında örgütlenen kooperatifler maddi hayatın yeniden üretiminde olduğu kadar sosyal, kültürel, yönetsel açılardan da belirli ilkelere sahiptir. Kooperatiflerin sadece ekonomik amaçlı örgütlenmeler olmadığını gösteren ilkeler; faaliyetlerin ortakların karşılıklı dayanışma ve yardımlaşma ilişkileri temelinde yürütülmesi, ortakların kooperatif yönetimine katılımda eşit oy hakkını sahip olması, ortakların toplu yarar ve gereksinimlerinin gözetilmesi ve hatta bireylerin toplumda yabancılık ve yalnızlıklarını önlemek için sosyal ilişki ve iletişimin geliştirilmesi olarak özetlenebilir. ${ }^{14}$

Örgütlenme tarzı olarak kooperatifçilik 19. yüzyıldan itibaren sosyal bilimciler, politikacılar, filozoflar tarafından yoğun olarak tartışılan konulardan biridir. Kooperatifler denilince akla öncelikle planlamacı, devletçi, sosyalist esaslara dayalı ekonomiler gelmesine rağmen birbirine karşıt ekonomik model ve yaklaşımları savunanlar dahi bu örgütlenme tarzının sağladığı toplumsal faydanın önemini teslim etmişlerdir. Ekonomik liberalizmin önemli isimlerinden J. S. Mill dahi "işçi kooperatiflerini" sosyal reformun olası araçları arasında saymıştır. ${ }^{15}$ Kooperatif hareketi denilince akla en çok gelen isimlerden biri

12 “Kooperatifler”, Modern Toplumsal Düşünce Sözlüğü içinde, der. William Outhwaite (İstanbul: İletişim Yayınları, 2008).

13 Ziyaeddin Fındıkoğlu, Kooperasyon Sosyolojisi: Nazari ve Tatbiki Kooperatifçilik Denemesi (İstanbul: İstanbul Üniversitesi Yayınları, 1974), 317.

14 Zeynep Sina ve Serap Soyer, "Sosyolojik Açıdan Kooperatifçilik Teorisinin Niteliğine İlişkin Düşünceler", Amme İdaresi Dergisi 31, no. 3 (1998): 104-108.

15 Aktaran Sina ve Soyer, "Sosyolojik Açıdan Kooperatifçilik”, 105. 
de ütopik sosyalistlerden Robert Owen'dır. İngiltere kapitalizminin gelişme sürecinde açığa çıkan işsizlik ve yoksulluğun yarattığı 1stırabın yaygınlaştığı yıllarda Owen, yoksulları "köy kooperatifleri"ne yerleştirmeyi önermiştir. ${ }^{16}$ Owen'e göre zenginler ve yoksulların, yönetenler ve yönetilenlerin gerçekte tek bir çıkarı vardır: Yeni bir ortak toplum kurmak. Bu şekilde sınıf çatışmalarının doğurduğu akılsız ve yararsız mücadeleler sona erecek ve avant garde (model topluluklar kurularak ve propaganda yoluyla) çalışan insanların, zenginlerin mülkiyet haklarını ve güçlerini açıkça pas geçecekleri bir yol ortaya çıkacaktı. ${ }^{17}$ İlerleyen süreçte İngiltere'de Owen'ın fikirleri ve yarattığ 1 akımla yaygınlaşan kooperatifçilik, rasyonalistlerle Hıristiyanların, Radikallerle siyasi bakımdan tarafsız olanlar gibi farklı felsefi, siyasi arka planlardan gelen kimselerin birlikte çalışabilecekleri bir hareket haline geldi. Owen'ın başlattığı kooperatifleşme hareketi, farklı siyasi çevrelerden gelen kimselerin işbirliği içinde kapitalizmin ürettiği eşitsizlikleri ve yoksullukları aşmaya çalışması ve bir alternatif üretmesi bakımından öğretici bir örnektir.

Fransa'da çeşitli siyasi toplulukların ortak harcamalarıla kurulan "kasap birlikleri", "bakkal birlikleri" adlı en eski kooperatifleşme deneyimleri, tekelci sermayenin hâkimiyeti altında olan tüketim süreçlerinde alternatif bir alan oluşturma iddiası taşımaktadır. Bu kooperatifler "karşılıklılık" gibi, üreticiler ve tüketicilerin birbirlerine karşılıklı olarak saygı duyduğu, adil bir fiyatla alışveriş yaptıkları yeni bir ilkeyle çalışırlar. ${ }^{18}$ Ancak Proudhon'a göre bu kooperatifler "birlik" adını taşımasına rağmen "birlik" özelliklerini çok az taşırlar. Çünkü "karşılıklılık" ve "birlik" ilkesi Fransa'da birçok kooperatifin kuruluş ilkesi haline gelmesine rağmen kooperatiflerin birçoğunda ortakların temsilciliğini yapan yöneticilere bağlı çok sayıda ücretli emek çalıştırılmaya devam edilmektedir. Bu eksikliklerine rağmen Proudhon, kooperatif tarzı birliklerin devlet ve sermaye karşısında küçük mülkiyet sahiplerinin korunmasında ve ast-üst ilişkilerinin ortadan kaldırılmasında tek çıkar yol olduğunu savunmaktadır. Marx kooperatif tipi fabrikaları, eski biçimler içinde yeni sistemin ilk nüvelerini barındırdığı için olumlu görür. ${ }^{19}$ Çünkü bu kooperatifler mevcut sistemin bütün kusurlarını yeniden üretmelerine rağmen emekçilere kendi kendilerinin kapitalistleri haline gelme, üretim araçlarını kendi emeklerinden yararlanmak için kullanma hakkı verir. Sermaye ile emek arasındaki karşıtlıklar kooperatifler aracılığıyla emek lehine çözülür. Marx'a göre bu tip kooperatifler yeni bir üretim tarzının eskisinden doğallıkla nasıl doğup büyüdüğünü gösterir. Dolayısıyla işçilerin yönetimde olduğu fabrika tipi kooperatifler hem eski hem de yeni üretim tarzının birlikte görülebildiği bir tür melez örgütlenmelerdir. İşçilerin kooperatif kurma çabalarını kendi ülkelerinde devrim yapmanın bir yolu olarak gören Marx, Alman Sosyal Demokrat Partisi'nin açıkladığı Gotha Programı́nda devlet yardımıyla işçilere ait üretim kooperatifleri kurulması önerisini şiddetle eleştirerek şöyle der: "Ve bugünkü kooperatifler ancak işçilerin elinde bağımsız kuruluşlar oldukları

16 E. P. Thompson, İngiliz İşçi Sınıfının Oluşumu, çev. Uygur Kocabaşoğlu (İstanbul: İletişim Yayınevi, 2006), 929-941.

17 Owen'in fikirlerine dayalı olarak adil değişim temelinde kurulan üretim ve tüketim ilişkilerinin İngiltere genelinde nasıl yaygınlaştığına ilişkin daha ayrıntılı bilgi için bkz. Thompson, İngiliz İş̧ Sıııfının Oluşumu, 934-940.

18 P. J. Proudhon, General Idea of The Revolution In The Nineteenth Century, çev. John Beverley Robinson (New York: Haskell House Publishers Ltd., 1969), 91.

19 Karl Marx, Kapital, üçüncü cilt, çev. Alaattin Bilgi (Ankara: Sol Yayınları, 2004), 392. 
ne hükümetler ne de burjuvalar tarafından korunmadıkları ölçüde bir değer taşırlar." 20

Lenin'de kooperatifler en ilkel türlerinden en gelişmiş türlerine dek bütün biçimleriyle (tüketim, kredi ve üretim), en başta köylüler olmak üzere, geniş emekçi yığınların sosyalizmin kuruluşuna doğrudan ve canlı bir biçimde katılımında en önemli araç olarak ele alınmaktadır. ${ }^{21}$ Ancak Lenin kooperatiflerin Almanya ve Rusya'daki kimi örneklerine de mesafelidir. Çünkü kırsal alanlarda zengin, orta ve küçük ölçekli üretim yapan köylülük biçiminde ortaya çıkan sınıfsal farklılaşmalar kendisini çoğu zaman kooperatiflerde de yeniden üretmekte, kooperatifin yarattığı imkânlar kırsal kesim arasında eşit olarak dağılmamaktadır. ${ }^{22}$ Marx'ta olduğu gibi Lenin'de de kooperatifler üretim ve tüketim süreçlerinde sosyalist tarzda örgütlenmenin araçları olarak görülmektedir. Sovyetler Birliği, Bulgaristan ve Macaristan örneklerinde kooperatif tipi örgütlenmeler özel mülkiyete dayalı sistemin mutlak anlamda alternatifi, kolektif mülkiyetin ve sosyalist tarzda ekonomik yapılanmanın temel kurumları haline gelmiştir.

Sosyalist ülkelerdeki kooperatifleşme deneyimleri ve anarşistlerin görüşleri kooperatifleşme kuramının önemli isimlerinden Kessler tarafından yoğun olarak eleştirilmiştir. Kessler'e göre devletin zoru ile değil, azasının serbest, hür iş beraberliği ilkelerinin Rusya'daki kooperatifleşme örneklerinde hayata geçmediği, köylülerin tabi tutulduğu mecburi teşekküllerin "kooperatif" ismi altında yad edilmesine rağmen bunların ancak hukuki olarak kooperatife benzediği üzerinde durmuştur. ${ }^{23}$ Aynı zamanda Kessler'e göre kooperatiflere çoğu zaman antikapitalist bir nitelik atfedilmesine rağmen üyelerine temettü dağıtan kooperatifler çoğu zaman kapitalist iktisadi düzene dahil kurumlardır.

1960'lardan itibaren modernleşme, ekonomik gelişme ve tarımsal kooperatifler arasındaki pozitif ilişkiler "Üçüncü Dünya" olarak adlandırılan ülkelerin kalkınma literatüründe önemli temalarından biri haline gelmektedir. ${ }^{24}$ Latin Amerika, Asya, Afrika ve diğer bölgelerde yer alan, nüfusun büyük bir kesiminin kırsal alanlarda yaşadığı ülkelerde kırsal kalkınmanın gerçekleştirilmesi ve yoksulluğun giderilmesi amacıyla kooperatifler daha çok devlet öncülüğünde organize edilmiştir. Geç kapitalistleşen ülkelerin gelişme ve büyüme süreçlerinde devletin aktif ve müdahaleci tutum alması buradaki kooperatifleşme deneyimlerinin de sermayeden ve devletten özerk gelişimini engellemiştir. Özellikle tarım kooperatifleri küçük üreticilerin daha büyük birlikler halinde ulusal ekonomiye katılabilmesi, ölçek artışının yarattığı imkânlardan yararlanabilmesi ve bu sayede üretici güçlerini ve pazarlama sistemlerini daha rasyonel ve verimli hale getirebilmesi için önemli araçlar olarak kabul edilmiştir. ${ }^{25}$ Ulusal kalkınmacı çizgi içinde gündeme gelen kooperatifleşme örneklerinin kapitalizme alternatif olmak yerine daha çok kapitalizmle eklemlenme sürecinde

20 Karl Marks ve Friedrich Engels, Gotha ve Erfurt Programlarının Eleştirisi (Ankara: Eriş Yayınlar1, 2004), 27.

21 Stoyan Sulemezov, Lenin Kooperatif Planı ve Bulgaristan Kooperatif Hareketi (Ankara: Bilim ve Sosyalizm Yayınları, 1976), 11.

22 V. I. Lenin, Tarımda Kapitalizm, çev. Serpil Güvenç (Ankara: Sol Yayınları, 1996), 187.

23 Gerdhard Kessler, Kooperatifçilik, çev. Ziyaeddin Fındıkoğlu (İstanbul: İstanbul Üniversitesi Yayınları, 1940), 6

24 Tom Brass, "How Agrarian Cooperatives Fail: Lessons From 1970s Peru”, The Journal of Peasant Studies 34, no. 2 (2007): 266.

25 Brass, "How Agrarian Cooperatives Fail”, 270. 
sağladığ1 avantajlar açısından değerlendirildiğini söylemek mümkündür.

Kapitalizmin 1970'lerden itibaren küresel ölçekte içinden geçtiği neoliberal sürece bağlı olarak metalaşma ve bireycileşme ekseninde toplumlar hızlı bir dönüşüm sürecine girerken, sosyal refah devletine ait kamusal düzenekler tasfiye edilmekte ancak kooperatif tipi örgütlenme modelleri önemini ve güncelliğini korumaktadır. Brezilya'da Topraksız Köylü Hareketi bünyesinde 1980'lerden bu yana faaliyette olan Tarımsal Üretim Kooperatifleri "kooperatifleşmenin en üstün formu" olarak görülmektedir. ${ }^{26}$ Katılımcı olarak yaklaşık 2200 üretici köylü ailesinin bulunduğu kooperatifler, Brezilya'da devletin uyguladığı neoliberal tarım politikaları karşısında köylülerin üretim ve ihtiyaçlar konusunda doğrudan tartışarak karar aldığ alternatif alanlar geliştirmeye çalışmaktadır. Bu kooperatifler bünyesindeki katılımcı köylü aileleri kendi içinde ortak bahçesi, mutfağ 1 ve okulu olan "agrovila" adı verilen birimlerde yaşamaktadır.

Başka bir deneyim kendisini komünist toplum olarak tanımlayan Çin'de yaşanmaktadır. ${ }^{27}$ Çin'de kadınlar toprak, kredi, iş, eğitim ve bilgi gibi çeşitli kaynaklara erişim konusunda yaşadıkları dezavantajları aşmak için çeşitli yerel kooperatiflere katılmaktadırlar. Yerel kooperatifler, uluslararası komite ve Çin Kadınlar Federasyonu gibi çeşitli kurumlar arasındaki yatay ilişkiler özellikle kadınların banka kredilerine erişimlerinde büyük imkânlar sağlamaktadır.

Diğer bir gelişkin kooperatif örneği 1900'lü yılların başında İsrail topraklarında kurulan, İsrail Devleti'nin kuruluşunda da rol oynayan ve bugüne kadar varlığını sürdüren Kibutzlardır. Kuruluş aşamasında 12 kişiyle, "herkesten yeteneğine göre, herkese gereksinmesine göre" ilkesiyle işe başlayan Kibutzlar kendi içinde hiyerarşik bir yapılanmaya izin vermeden tarım, sanayi, eğitim ve turizm gibi oldukça farklı alanlarda örgütlenmiştir. ${ }^{28} 2010$ verilerine göre toplam 273 Kibutz'da çalışan 125 bin kişi, İsrail tarımsal üretiminin yüzde 34'ünü gerçekleştirmekte ancak son yıllarda metalaşma, özelleştirme gibi süreçler Kibutz kooperatiflerini de olumsuz etkilemektedir. ${ }^{29}$

\section{Türkiye'de Kooperatifleşme Deneyimleri}

Osmanlı'da kooperatifçiliğin ilk örnekleri imparatorluğun kapitalistleşme sürecine giren ve dünya pazarlarıyla eklemlenen tarımsal alanlarında ortaya çıkmıştır. Türkiye'de kooperatifleşmenin tarihini konu alan kaynaklarda üzerinde sıklıkla durulan örneklerden ilki 1863 yılında Mithat Paşa tarafından kurulan Memleket Sandıkları adlı kredi kooperatifidir. Osmanlı'nın çeşitli bölgelerinde yaygınlaştırılan bu kooperatif girişiminin sermayesini çiftçilerin köyün ortak malı olan topraklarda yürüttükleri ortak tarımsal faaliyetlerden sağlaması amaçlanmıştır. ${ }^{30}$ Aydın'da Aydın Himaye-i Zürra Anonim Şirketi adı taşıyan başka bir kooperatif, vergiden ve denetimden muaf tutulan İngiliz sermayeli The Smyrna Fig Packers Limited isimli ihracat firmasının tekelci faaliyetlerine

26 Anthony Pahnke, "Institutionalizing Economies of Opposition: Explaining and Evaluating the Success of the MST's Cooperatives and Agroecological Repeasantization", The Journal of Peasant Studies 42, no. 6 (2015): 1096.

27 Leslie Sklair, Globalization: Capitalism and Its Alternatives (Oxford: Oxford University Press, 2002), 303.

28 İbrahim Yasa, "Kibbutz'un Toplumsal İdeolojisi ve Yapısı", Ankara Üniversitesi Siyasal Bilgiler Fakültesi Dergisi 27 (1972): 10.

29 Güven Şahin ve Nuran Taşlıgil, "Kolektif İşletme Tiplerine Tipik Bir Örnek: Kibbutzlar”, Adıyaman Üniversitesi Sosyal Bilimler Enstitüsü Dergisi 9 (2012): 217.

30 Nabi Dinçer, “Türkiye'de Kooperatifçilik", Cumhuriyet Dönemi Türkiye Ansiklopedisi, cilt 9 içinde (İstanbul: İletişim Yayınları, 1985), 1274. 
karşı incir üreticilerini korumayı amaçlamıştır. 1915 yılında kurulan ancak Osmanlı́nın son dönemlerinde kooperatifçilik mevzuatının yetersizliği nedeniyle anonim şirket adını alan bu kooperatif daha sonra TARIŞ'e dönüşerek varlığını sürdürmüştür. ${ }^{31}$ Ancak tarımda kooperatifçiliğin ilk örnekleri, Osmanlı'nın tarımsal yapısında dini ve etnik kimliği ne olursa olsun tüccar karşısında küçük köylüyü korumak amacından daha çok iktisadi ve ticari hayat içinde ayrıcalıklı bir konuma sahip olan yabancı ve gayrimüslim tüccar karşısında Müslüman-Türk ticaret burjuvazisini korumak hedefleri taşımıştır. ${ }^{32}$

Cumhuriyet Dönemi'nde kurulan kooperatifler büyük ölçüde merkezi devletin girişimiyle ulusal kalkınma hedefleri doğrultusunda organize edilen örgütlenmelerdir. 1931 yılında Mustafa Kemal tarafından kurdurulan Türk Kooperatif Cemiyeti'nin açıklamalarında dünyanın geçirdiği büyük iktisadi buhran ve inkılâptan memleketimizin mümkün mertebe az müteessir olması ve milli sermayenin birikmesinin yolunun iktisadi kooperatifçilikten geçtiği tezleri üzerinde durulmaktadır. ${ }^{33}$ Devamında Türkiye'de kooperatifçiliğin temel esasları belirtilirken "diğer taraftan da kooperatifçilikte mülkiyet hakkını selbeden, kolektivizme kadar gitmek isteyen cereyanlardan uzak olduğumuzu tebarüz ettirmeyi lüzumlu görüyoruz" denilmektedir. Ayrıca "istismar edici sermayenin diktatörlüğünün de kabul edilmemesi" cemiyetin kooperatifçiliğe bakış açısının diğer bir önemli boyutudur. Bu ifadeler göstermektedir ki Cumhuriyet'in kuruluş yıllarında kooperatifçilik, sosyalist deneyimler ve sermayenin mutlak egemen olduğu kapitalist deneyimler dışında bir seçenek olduğu kabul edilen ulusal kalkınmacı bir çizgi içinde işlev kazanmaktadır.

1929 ekonomik krizi sonrası tarımın yeniden yapılandırılması ihtiyacı, kırsal nüfus ve istihdamın büyük bir kesiminin kırda yer alması, iktisadi kalkınmada küçük köylü üretimine öncelik verilmeye başlanması, üretimi yeniden canlandıracak tabandan gelen girişimlerin zayıf olması gibi çok sayıda etken, merkezi devleti kooperatiflerin kurulmasında asli roller oynamaya zorlamıştır. ${ }^{34}$ Merkezi devlet girişimleri yanında aydınlar, ziraat memurları ve Türkiye'nin dört bir yanına dağılan öğretmenler köylerde kooperatifleşme çabalarının başlatılması hususunda öncü kişiler olarak görülmüştür. 1930'ların başından itibaren uygulamaya geçilen tarımsal destekleme programına eşlik eden kooperatifleşme deneyimleri yasal, düşünsel ve örgütsel açıdan gelişmeye başlamış, 1960'ların başından itibaren daha yaygın bir karakter kazanmıştır. Fiskobirlik, Çukobirlik, Antbirlik gibi Türkiye'de devlet merkezli olarak kurulan kooperatifler, üreticiler için uygun asgari fiyatların oluşması, pazarlama ve nakit akışının çözülmesi gibi düzenleyici işlevleri yerine getirerek tarımda küçük üreticileri içeren, yaygın bir işçileşmeye izin vermeyen bir sermaye birikim rejiminin oluşmasına katkılar sağlamıştır.

Özelikle 1990 ve 2000'li yıllarda kapitalizmin küresel ölçekte düzenleyici kurumları olan IMF ve Dünya Bankası ile yapılan anlaşmalara bağlı olarak devlete ait tarımda faaliyet gösteren destekleyici kooperatif ve kuruluşlar tasfiye sürecine girmiştir. Hayvancılık ve süt sektöründe kooperatife benzer işlevleri

31 Hakkı Çetin, “Kamu Ekonomisi Yönünden Tarım Satış Kooperatifleri Birliklerinin Fonksiyonları", Vergi Sorunları Dergisi 297 (2013): 156.

32 Ballı, "Türkiye'de Tarımsal Kooperatifçiliğin Gelişimi", 12.

33 Nusret Uzgören, Atatürk Kooperatifçilik ve Türk Kooperatifçilik Kurumu (Ankara: Türk Kooperatifçilik Kurumu Yayınları, 1983), 27-28.

34 Çelik Aruoba, "Tarımsal Kalkınmada Kredi Kooperatiflerin Önemi Üzerine Bazı Düşünceler", Siyasal Bilgiler Fakültesi Dergisi 26, no. 2 (1971): 113. 
yerine getiren, 1963 yılında kurulan Süt Endüstrisi Kurumu (SEK) bunlardan biridir. Süt ve süt ürünleri piyasasında özel sektörle rekabet edebilen ve özel sektörün süt piyasasındaki tekelleşme eğilimlerine sınırlar getirebilen SEK'in özelleştirme süreci 1990 'l 1 yılların ortasında tamamlanmıştır. ${ }^{35}$ Özelleştirme sürecinin tamamlanmasıyla sütün üretim ve pazarlama süreçleri üzerinde Danone, Pınar, Sütaş gibi yerli ve çokuluslu firmaların etkinliği artmıştır. Bu süreç kendisini küçük üreticiler üzerinde artan piyasa baskısıyla, tüketiciler üzerinde de giderek sağlıklı ve güvenilir besin olma özelliğini yitiren süte daha yüksek fiyatlar ödenmesi biçiminde göstermektedir. Devletin düzenleyici rollerinden çekildiği, merkeze bağlı kooperatiflerin tasfiye edildiği bir süreçte sütün üretim, dolaşım ve gıda güvenliği boyutuyla dayanışma ve işbirliği temelinde yeniden organize edilmesi büyük önem taşıyan bir mesele haline gelmiştir. Tire Süt Kooperatifi ve İzmir Büyükşehir Belediyesi arasında yerelde kurulan işbirliği temel bir ihtiyaç olan sütün üretim, pazarlama ve gıda güvenliği süreçlerinde alternatif modellerin mümkün olabildiğini göstermiştir.

\section{Yerelde Alternatif Kamusallı̆̆ın Aktörleri: İzmir Büyükşehir Beledi- yesi ve Tire Süt Kooperatifi}

İzmir yerelinde küçük üreticiler, kooperatifler, büyükşehir belediyesi ve kentteki tüketiciler arasında hiyerarşik olmayan yatay bir bütünleşme oluşturularak tarımda üretim, tüketim ve pazarlama süreçlerinin farklı bir anlayışla organize edildiği alternatif bir kamusallık deneyimi yaşanmaktadır. Alternatif kamusallık kavramı ise sermayenin hâkimiyetinin yarattığı sorunları, bu sorunların mağdurları lehinde telafi edici biçimlerde çözmeye çalışan söz ve eylemlerin alanı olarak tanımlanmıştır. ${ }^{36}$ Alternatif kamusal alanın baş aktörleri olabilecek kamular, toplumsal hareketler ve örgütler, hükümet dışı kuruluşlar ve özellikle de özerk sivil yapılardır. Bu yapılar aracılığıyla kamu yararının gözetilmesi, herkesin eşitçe erişebileceği kamusal hizmetin verilmesi ve kullanım değeri temelli üretim, alternatif kamusallığın çeşitli yönleri olarak ele alınmaktadır. ${ }^{37}$ Tire Süt Kooperatifinin belediyeyle kurduğu işbirliği temelinde yürüttüğü alternatif örgütlenme modelinin ayrıntılarına geçmeden önce bu kooperatifin ayağa kalkması ve güçlenmesinde destek ve teşvikleriyle önemli bir payı olan İzmir Büyükşehir Belediyesi'nin kooperatifleşme politikası ve uygulamalarına kısaca değinmek gerekir.

\section{İzmir Büyükşehir Belediyesi}

İzmir Büyükşsehir Belediyesi'nin çevredeki kırsal alanlara yönelik çalışmaları son yıllarda yapılan bir dizi yasal düzenlemeyle birlikte hız kazanmıştır. 2004 yılında uygulamaya giren 5216 sayılı Büyükşehir Belediyesi Kanunu ve 12 Kasım 2012'de kabul edilen 6360 sayılı yasayla birlikte İzmir Büyükşehir Belediyesi'nin görev alanı İzmir çevresindeki tarımsal alanlara doğru genişlemeye başlamıştır. ${ }^{38}$ İzmir Büyükşehir Belediyesi, görev alanına giren tarımsal alanlarda etkinliğini artırabilmek amacıyla kendi bünyesinde Tarımsal Desteklemeler Daire Başkanlığı'nı kurarak iki hedefi yerine getirmeye çalışmıştır. Bunlardan

35 Necdet Oral, Türkiye Tarımında Kapitalizm ve Sinıflar (Ankara: TMMOB Yayınları, 2006), 233.

36 Meral Özbek, der., Kamusal Alan: Politik Kamusal Alan ve Kolektif Yaratıcllik (İstanbul: Hil Yayın, 2002), 182, 202.

37 Alternatif kamusallık kavramı etrafında yapılan başka bir teorik tartışma için bkz. Koray R. Yılmaz, "Alternatif Kamusalın Politik Ekonomisi: Teorik Bir Tartışma 'Genel Olarak Sermaye'den 'Genel Olarak Birliğe'”, Praksis 30-31 (2013): 257-274.

38 “Kırsal Kalkınmada İzmir Modeli”, 4 Mevsim 5, no. 17 (2016): 22-24. 
birincisi, tarımsal faaliyetlerin kalkınmanın yerelden başlamasını sağlayacak biçimde gelişmesini sağlamaktır. İkincisi ise İzmir'deki tarımsal gelişmenin çevreye dost, sürdürülebilir nitelikte olmasını gerçekleştirmeye yöneliktir. ${ }^{39}$ İzmir Büyükşehir Belediyesi'nin geliştirdiği projeler oldukça kapsamlı olmakla birlikte burada esas olarak kooperatiflerin desteklenmesi yoluyla küçük üreticiliğin güçlendirilmesi ve bu yolla kırsal kalkınmanın sağlanması hedefleri üzerinde durulacak. İzmir Büyükşehir Belediyesi yerelde küçük üretici, kooperatifler, belediye ve kentteki tüketici arasında bir tür yatay ve eşitlikçi bir entegrasyon modeli oluşturmaya çalışmaktadır. Bu modelde, tarımda aile emeğiyle üretim yapan küçük üreticiliğin güçlendirilmesi, üretimin insan sağllğına uygun yapılması ve ürünün kooperatifler aracıllı̆ıyla en uygun fiyata tüketiciye ulaştırılması hedeflemektedir. Oluşturulan bu modelin arkasındaki temel ilkeler "sosyal belediyecilik" ve "yerelde kalkınma" olarak tanımlanmaktadır.

Belediye tarafından küçük üreticilere meyve fidanı dağıtımı, organik tarım eğitimi, verimlilik artıracak donanım desteği, toprak analizleri, tohum, küçükbaş ve arıcılık malzemeleri dağıtımı gibi çok yönlü ücretsiz destekleme programı uygulanmaktadır. Geniş bir ürün yelpazesinde alım ve dağıtım yapan belediye alımlarını mümkün olduğunca üretici kooperatifleriyle işbirliği ve karşılıklı sözleşmelerle yapmaktadır. İzmir Büyükșehir Belediyesi tarafından Tire, Ödemiş, Bademli, Urla, Kiraz, Zeytinova, Gödence, Pamukyazı, Derebaşı, Mordoğan, Bayındır gibi geniş bir çevrede yer alan tarım satış ve kalkınma kooperatifleri aracılığıyla, aile emeğiyle üretim yapan küçük üreticiler çeşitli tarım ürünleri üretiminde düzenli olarak desteklenmektedir. ${ }^{40}$ Ayrıca tarımsal destekleme programı toplumsal cinsiyet duyarlılığı da taşımakta, kadın üreticilerin yetiştirilmesi amacıyla özel eğitim programları düzenlenmektedir. Belediye tarafından çilek gibi bazı ürünlerde sadece kadın üreticiliğinin gelişmesi için fide ve teknik destek verilmektedir.

Tarımın üretim ayağında yer alan küçük üreticiler, kooperatifler ve köyler yapılan alım garantileri ve ekipman desteklerinden olumlu etkilenirken aynı zamanda kentteki tüketicilerin sağlıklı, ucuz ve hatta ücretsiz olarak temel gıda ürünlerine ulaşımı sağlanmaktadır. Bu anlamda üretici, kooperatif, belediye ve tüketiciler arasında kurulan alternatif üretim, dağıtım kanalı "Okul Sütü" ve "Süt Kuzusu" projeleriyle belki de en somut halini bulmuştur. 2008 yılında uygulanmaya başlanan "Okul Sütü" Projesiyle Tire Süt Kooperatifi'ne bağlı süt üreticilerinin pazarlama sorunları çözüldüğü gibi aynı zamanda İzmir'de beş yıl boyunca 220 okulda 240 bin öğrenciye ücretsiz süt dağıtımı yapılmıştır. ${ }^{41}$ Bu projenin başarısıyla Hükümet “Okul Sütü" projesini tüm Türkiye’ye yaymış ancak bu gelişmeyle İzmir Büyükşehir Belediyesi'yle kooperatifler arasında süt üretim ve dağıtımına dayalı işbirliğinin zemini de ortadan kalkmıştır. Belediye 2012 yılından itibaren "Süt Kuzusu" adlı yeni bir projeyle okula gitmeyen, 0-5 yaş arası çocuğu olan yaklaşık 125 bin ailenin doğrudan evlerine kadar ulaşan bir dağıtım sistemi kurmuştur. İzmir'de kooperatifçiliğin başarılı örneklerinden Tire Süt Kooperatifi bu proje kapsamında belediyeyle sözleşmeli üretim yaparak çocuklara sağlıklı, pastörize süt temin edilmesinde önemli rol oynamaktadır.

39 Tekeli, İzmir İli/Kenti İçin Bir Tarımsal Gelişme, 99.

40 Ertuğrul Tugay, “İBB'nin Tarıma ve Kırsal Kalkınmaya Yönelik Çalışmaları Yayınlanmamış Bilgi Notu" (İBB Tarımsal Desteklemeler Daire Başkanlığı, 2016), 6.

41 Tire Süt Kooperatifi Tanıtım Kitapçı̆̆ı (Tire, 2017), 1. 


\title{
Tire Süt Kooperatifi
}

Türkiye'de kooperatif tipi örgütlenmelerle ilgili toplum genelinde genel bir güvensizlik hali ve olumsuz imaj varlığını sürdürmesine rağmen Tire Süt Kooperatifi, İzmir çevresi ve Tire'de hem üreticiler hem de kent halkı tarafından ürünlerine ve çalışma ilkelerine güvenilir bir kurum olarak bilinmektedir. 1967 y1lında kurulan Tire Süt Kooperatifi bugün 2000'in üzerinde ortak say1siyla Türkiye'nin en büyük süt kooperatiflerinden biri haline gelmiştir. Tire Süt Kooperatifi deneyimi, İzmir yerelinde küçük üreticiler, kooperatif, belediye ve tüketiciler arasında kurulan güven ve işbirliğine dayalı eşitlikçi ilişkiler içinde anlam kazanan bir örgütlenmedir. Bu model içinde kooperatif işleyişinin çeşitli öğeleri olan yönetim, üretim, piyasa, gıda ve tüketim süreçleri alternatif kamusallığın örüldüğü çeşitli alanlar haline gelmektedir. Bu süreçlerin ayrıntısına girmeden önce Tire Süt Kooperatifi işleyişinin temel ilkeleri üzerinde durmak gerekiyor.

\section{Tire Süt Kooperatifi'nin Temel İşleyiş İlkeleri}

Kendisi de çiftçilik yapan kooperatif başkanı tarımda küçük aile şirketlerinin tasfiye edilip tarımın şirketlerle yapılmasını öngören zihniyete karşı "tekelleşme yerine kooperatifleşme" esaslı kırsal kalkınma modelini savunduklarını belirtir:

\begin{abstract}
Kapitalist sistem içinde küçük üreticilerin yaşama şansı yok. Yaşayabilmesinin tek koşulu var: Birlik olmak. Birlikte çalışma anlayışına sahip olmak yani kooperatifleşme. Çünkü Türkiye'nin yüzde yetmişi küçük aile işletmesi. Büyük bir kısmı 50 dekarın altında tarım yapan nüfustan söz ediyoruz. Ben de diyorum ki küçük aile işletmelerini yok ederek yeni büyükler yaratmayalım. Onları yok etmeden birleştirerek büyük ölçek haline getirelim yani kooperatifleşmeyi ön plana atalım. ${ }^{42}$
\end{abstract}

Kooperatif başkanının kooperatifleşme meselesinde tarımda yüksek kâr anlayışına dayalı olarak çalışan, bu uğurda küçük üreticiler ve toplumun diğer kesimleri ve doğa üzerinde tahribatlar yaratmaktan çekinmeyen tekellere yönelik bir eleştiriden hareket ettiği görülmektedir. Küçük üreticiliğin üretimle bağının güçlendirilmesi ve kooperatifler yoluyla planlı, ucuz ve sağlıklı gıda üretimine geçilmesi göç, işsizlik ve gıda krizlerinin yol açtı̆̆ı sorunların çözümünde büyük önem taşımaktadır. Aşağıda kooperatif başkanının açıkladığı gibi birlik, güven, eşitlik ve işbirliği gibi ilkeler dünyada ve Türkiye'de çeşitli örneklerde görüldüğü gibi kooperatif işleyişinin temel ilkeleri olarak kabul edilmiştir.

Bu büyümenin asıl temelinde yatan burada sağlıklı bir yapının oluşmasıyla ilgili. Güven duygusu. Ben bir kere inanarak yola çıtım ve kimseye ayrımcılık, siyasi ayrımcılık, yandaş ayrımcılığı yapmadığımız için de ortaklar arasında bir güven oluştu. Burada herkes eşittir. Yönetim kurulunun dahi ortaklardan bir farkı yoktur. Hiç kimseye ayrımcılık olmaz. İşte bu güvenden dolayı, birbirine kenetlenerek böyle bir yapı oluşturdular. [Ortaklar] Bir güç oluşturdular. ${ }^{43}$

Tire Süt Kooperatifi, kendisi aile emeğiyle tarım ve hayvancılık üretimi yapan ortakların birliğini sağlayarak, buradan aldığı güçle piyasa ve fiyatlar üzerinde ortaklar lehine müdahalelerde bulunarak üretimin organizasyonu, satış ve pazarlama süreçlerini düzenlemeyi amaçlamaktadır. Aşırı kâr güdüsüyle hareket

42 Tire Süt Kooperatif Başkanı Mahmut Eskiyörük, Tire, 15 Mart 2017.

43 Tire Süt Kooperatif Başkanı Mahmut Eskiyörük, Tire, 15 Mart 2017. 
etmediğinden üretim, pazarlama ve tüketim süreçlerinde emek, doğa ve ürün ekseninde belirli iyileşmeler sağlayabilmektedir. Yönetim ve diğer kooperatif faaliyetlerinde siyasi ayrımcılık ve kutuplaşmaya izin verilmemekte, ortaklar arasında güven ve birlik anlayışı tesis edilmeye çalışılmaktadır. Bu ilkeler etrafında oluşturulan güç kooperatifin süt piyasasındaki düzenleyicilik konumunu da güçlendirmektedir.

\section{Yönetsel Süreçler}

Belediye ve Tire Süt Kooperatifi arasındaki yatay ve hiyerarşik olmayan alternatif kamusallık modeli sadece sağladığı ekonomik avantajlarla değil üretimin ve tüketimin demokratikleştirilmesi anlamında da çeşitli olanaklar taşımaktadır. Yönetim boyutuyla bir karşılaştırma yapılacak olursa: Şirketler ve diğer sermaye grupları sadece sermaye sahipliğinin verdiği güçle, tek taraflı ve bireyselleştirilmiş kâr maksimizasyonu amacıyla üretim süreçlerini ve piyasayı düzenlemeye çalışır. Oysa üzerinde durduğumuz kamusal alanda bu süreçleri düzenleyen ve aktif olarak yer alan kooperatif ve belediye yönetimleri görece demokratik kontrol ve denetim mekanizmalarının işlediği kurum ve örgütlenmelerdir. Kooperatif yönetiminin kendi ortaklarıyla da işbirliği içinde olduğu belediyeyle de aralarında hiyerarşik bir ilişkiden söz edilmez. Tire Süt Kooperatifi düzenli olarak genel kurullar yapar ve ortakların doğrudan katılımıyla, seçimler yoluyla yönetici kadrosunu oluşturur. Tire Süt Kooperatifi'nde yönetsel süreçlerde kendisini gösteren görece demokratik yapısı sayesinde üreticiler üretim, dolaşım, pazarlama ve tüketim organizasyonuna yönelik kendi politikalarını oluşturma ve bu politikaları düzenleyici müdahaleler ve planlamayla hayata geçirme şansını bulur. Bu süreçler çerçevesinde Tire'nin bir köyünde üretilen sütün kalitesi, sütün nasıl pazarlanacağını ve hangi fiyatlar üzerinden nakde dönüşeceğini yine üreticinin kendisi karar verir. Böylece üreticiler sermayenin piyasa ve fiyatlar yoluyla kurduğu baskıya maruz kalan, üretimle bağ zayıflayan pasif aktörler olmak yerine içinde bulundukları piyasaya müdahale eden, düzenleyen ve yön veren aktif özneler konumuna ulaşırlar. Dolayısıyla Tire Süt Kooperatifi üreticilere tarımda kamusal alanın aktif özneleri olma imkânı sağlamakta ve bu sayede üreticiler kendi ürünleri üzerinde söz sahibi olabilmektedirler.

\section{Süt ve Süt Ürünleri Piyasasında Dengeleme Fonksiyonu}

Kooperatif çok sayıda üreticinin birlik halinde hareket etme gücünden yararlanarak toplu alım yapabilmekte ve ortaklara akaryakıt, yem, gübre, tohum gibi çeşitli üretim girdilerini piyasa fiyatlarının altında fiyatlarla tedarik edebilmektedir. Kooperatifin kendi mısır silajı ve yem üretim birimlerini de kurabilmiş olması ortakların avantajlı fiyatlarla girdi alımını kolaylaştırmaktadır. Kooperatif misır silajı paketleme tesisi için Küçük Menderes Ovası'nda yer alan üreticilerden belirli bir fiyattan mısır alımı yapmakta böylece hayvan yemi piyasasını da üreticiler yararına düzenleyebilmektedir. Ayrıca ortaklar kooperatifin tesislerinden indirimli akaryakıt imkânı sağlayabilmektedir. Alım gücü olmayan üreticiler ortak makine parkurundaki kooperatife ait traktörleri alıp sırayla kullanabilmekte ve ekimini, biçimini, paketleme ve mısır silajını yapabilmektedir. Her ortağın tek tek aynı alet ve ekipmanlardan satın almasına gerek kalmaması, çiftçi ortakların tarımsal makine ve diğer girdi piyasalarındaki sermaye gruplarına olan bağımlılığını büyük ölçüde azaltmaktadır. Üretici ortaklardan biri kooperatifin sağladığı girdi desteğini şöyle anlatıyor: 
İlacını, yemini, samanını dışarıdan aldın mı bu işi yapamazsın. Yemi, silajı dışarıdan alan bir üretici için maliyet artar. Bu adam para kazanamaz. Özel sektörle iş yapan var mesela. Kimi parasını alamaz. Bizde öyle sıkıntı olmaz. Alo deriz yem gelir. Alo deriz gübre gelir. Beş kuruş paran olmasın Tire'ye git kooperatiften her ihtiyacını alırsın. Kooperatif mağazasından a'dan z'ye her şeyini alırsın. ${ }^{44}$

Ortaklar ihtiyaç duyduğu an mazot, gübre ve diğer ekipmanlarla ilgili girdi desteğini para ödemeksizin sağlayabilmekte, karşılığını daha sonra kooperatife ürün vererek ödeyebilmektedir. Makine ve diğer ekipmanların üreticilerin ortak kullanımına sunulmuş olmasıyla üreticiler daha küçük bütçelerle süt üretimini gerçekleştirebilmektedir. Bu tip ortak makine kullanımı yanında kooperatifin mali darboğaza giren ortaklarına uygun koşullarda kredi sağlaması üretici ortakların banka, tefeci ve girdi üreten diğer sermaye gruplarına olan bağımlılığını büyük ölçüde azaltmaktadır. Ayrıca üreticilerin daha düşük maliyetlerle üretimi organize edebilmeleri, kooperatife temel bir gıda ürünü olan sütü daha düşük fiyatlarla pazara ulaştırma şansı da vermektedir. Kısacası kooperatifin üretimi düzenlemesi sadece küçük üreticilerle sınırlı etkiler yaratmamakta sonuçları itibarıla tüketicileri de olumlu etkilemektedir.

Tarım Bakanlığı tarafından piyasada düzenleyici aktör olması amacıyla kurulan Ulusal Süt Konseyi'nin etkisiz kalması, fiili olarak piyasa fiyatlarının büyük şirketler tarafından belirleniyor olması küçük üreticileri fiyat dalgalanmalarına karşı korumasız ve güvencesiz bırakmaktadır. Özellikle Süt Endüstrisi Kurumu gibi düzenleyici devlet kurumlarının tasfiye edilmesi küçük üreticileri çokuluslu ve yerli şirketlerin spekülasyonlarına karşı daha korumasız hale getirmiştir. Ülke genelinde büyük şirketler etkinliğini artırırken İzmir'de Tire Süt Kooperatifi sütü küçük üreticiler lehine olacak şekilde litre fiyatı 1,20 TL'den düzenli satın alarak süt piyasasında düzenleyici bir rol üstlenmiştir. ${ }^{45}$ Kooperatif girdi ve süt piyasasında yaptığı düzenleyici müdahalelerle birlikte şirketlerin tekelci faaliyetlerine ve tüccar, tefecilerin üretici üzerindeki baskılarına karşı Tire'de kendisine bağlı üretici ortaklar için koruyucu bir alan yaratabilmektedir.

Üç-beş sene önce [sütünü kooperatife vermeden önce] fiyatlar çok oynardı. Biz de [ekonomik olarak] geri giderdik. Kendimizi toparlayana kadar birkaç sene geçerdi. O zaman büyük şirketlere bağlıydı fiyatlar. Özel sektör beş on kuruş fazla verip sütü kendisi almak ister ama sonra fiyat düşürürdü. Oraya [şirkete] döndün mü hemen fiyatı indirirdi. Vatandaş parasını alamazdı. Nasıl olsa geri dönemeyeceğini bilirdi. Şimdi kooperatiflerle çalışmaya başladık. Dördüncü sene oldu. Allaha şükür fiyatlarımızda geri çekme olmadı. Bu okul sütü projelerinin bize çok faydası oldu. Diğer bölgelerde fiyatlar düşse dahi biz bundan etkilenmeyiz. Çanakkale'de, Balıkesir'de süte şu veya bu fiyat verilmiş. Şimdi biz buna uymak zorunda değiliz. Çevreye baktığın zaman bunlar bizden aşağıya düşüyor. ${ }^{46}$

Özellikle belediyenin halka düzenli ücretsiz süt dağıtma politikası sayesinde pazarlama ve nakit akışı sorunu çözülen kooperatifin düzenli alım, satım yapabilmesi üretici üzerinde olumlu etkiler yaratmıştır. Kooperatifin belirli bir fiyattan düzenli alım yapabilmesi ve diğer firmalar karşısındaki rekabette üstünlük kazanmasında belediyeyle kurulan işbirliğinin payı büyüktür. Eğer

44 Tire Süt Kooperatifi'ne Bağlı Üretici Ortak, Tire, 15 Mart 2017.

45 Sütün litresine verilen 1,20 TL, Mart 2017'de belirlenen fiyattır.

46 Tire Süt Kooperatifi'ne Bağlı Üretici Ortak, Tire, 15 Mart 2017. 
belediye kooperatiften belirli bir fiyattan düzenli alım yapmasaydı kooperatif içinde bulunduğu süt piyasasında firmaların fiyat baskısına daha çok maruz kalacak, maliyetleri düşürmeye çalışacaktı. Bunun da üretimden, süt kalitesine ve dağıtıma kadar çeşitli süreçlerin maliyetlerin düşürülmesi ilkesine göre yeniden düzenlenmesi ve kooperatifleşmenin temel ilkelerinden uzaklaşılması gibi sonuçları olabilecektir. ${ }^{47}$ Sütün pazarlama sürecindeki düzen ve istikrar, üretim ve piyasadaki arz ve fiyat durumuna da yansımaktadır. Böylece üreticiler önünü görerek üretimi sürdürebilmektedirler. Burada kooperatifle belediye arasındaki yatay ilişkilere dayalı alternatif kamusallık, girdi ve ürün piyasasındaki dalgalanmaları önlediği gibi üreticilere üretimi bağımsız sürdürme olanağı da vermektedir. Şirketler, tüccar ve tefecilerin fiyat spekülasyonları ve borçlandırma yoluyla üreticilere verdiği zararlar nedeniyle İzmir çevresindeki üreticilerde kooperatifin koruyucu önlemlerinin ne kadar önemli olduğu çok iyi anlaşılmıştır. Bu durum kooperatife katılım gösteren ortak sayısında hızlı artışlara yol açmıştır. 2001 yılında 580 olan üretici ortak sayısı 2016 yılına doğru yaklaşık dört kat artarak 2093'e ulaşmıştır. ${ }^{48}$ Aynı dönem içinde günde 28 ton alım yapan kooperatifin alım yaptığı süt miktarı 285 tona ulaşmıştır. Süt üretim miktarı Türkiye genelinde 2006-2016 yılları arasında yüzde 70 artarken Tire'de yüzde 440 gibi bir artış sağlamıştır.

\section{Gıda Güvenliği}

Üreticiler kooperatif ve belediyenin sağladığı alternatif üretim ve dolaşım alanında yer alarak piyasanın maliyet düşürme baskısından ve toprak, hayvanlar üzerinde kimyasal kullanma zorunluluklarından belirli ölçülerde bağımsiz davranabilmektedirler. Tire Süt Kooperatifi de maliyetleri yükseltmesine rağmen gıda güvenliği standartlarını oluşturmak amacıyla çok sayıda önlem almaktadır. Kooperatif süt ürünlerinde gıda güvenliğinin sağlanması için sayısı iki bini geçen bütün ortakların günlük verdiği sütü tek tek yerinde kontrol ettiği gibi ilaç, antibiyotik kullanımı tespitleri için gerekli analizleri yaparak satın almaktadır. Denetim ve kontrolde dört mühendis çalıştırılmakta, ortaklardan alınan numunelerin tamamının laboratuvar analizleri yapılmakta; bu da sütte litre başına ortalama iki kuruşluk bir maliyet artışı yaratmaktadır. Üretimde maliyet artışına rağmen kooperatif gıda güvenliği standartlarından taviz vermemektedir. Kooperatif başkanının açıklamalarına göre bu maliyet artışı diğer şirketler karşısında bir dezavantaj yaratmasına rağmen alınan önlem ve kontroller sayesinde Tire'de sütün kalitesi Avrupa kalite standartlarının dahi üstüne çıkmaktadır. Ayrıca kooperatif, sütün kalite değerlerine göre fiyatlandırma yaparak üreticiyi daha yüksek kalitede süt üretmeye teşvik etmektedir. Sütün kalitesini korumak amacıyla Tire'nin dağ köyleri de dahil 60 köyün ortak kullanımına soğutma tankları verilmiştir. Üreticinin verdiği süt miktarı fark etmeksizin kooperatif bütün ortaklar için soğutma tankı sistemi ve süt alım merkezleri kurmaktadır. Kooperatifte beş tane ineği olan ortakla 50 tane ineği olan ortağın haklarının eşit olduğu dile getirilmekte ve bütün ortaklar yukarıda sayılan çeşitli hizmetlerden ve soğuk zincirden yararlanabilmektedir.

47 Örneğin İspanya'nın Bask Bölgesi'nde 1956 yılında kurulan ve bugün 147 şirketi bünyesinde barındıran ve 80.000 çalışanı olan Mondragon işçi kooperatifi, kuruluşundaki özelliklerinin çoğunu, diğer firmalarla rekabet etme zorunluluğu nedeniyle giderek yitirmek zorunda kalmıştır. Ümit Akçay, "Ekonomik Demokrasi Ama Nasıl? Planlama Yeniden" Başlangıç, 13 Mart 2015, http://baslangicdergi.org/ekonomik-demokrasi-ama-nasil-planmala-yeniden, erişim tarihi 22 Mayıs 2017.

48 Üretici ortak sayılarındaki artış ve üretim miktarlarıyla ilgili veriler Tire Süt Kooperatifi yönetici ve uzmanlarından alınmıştır. 
Kooperatif ve belediye arasındaki işbirliğine dayalı alternatif kamusallık alanı üretim, piyasa ve gıda boyutuyla olduğu kadar pazarlama ve dağıtım süreçleri açısından da önemli imkânlar sağlamaktadır. Son yıllarda gıda tedarik ve dağıtım zincirleri içinde çok sayıda aracı tüccarın ve süpermarketin yer alması hem üretici hem de tüketici üzerinde çok sayıda olumsuz etki yaratmıştır. Aracılar kendilerine bağımlı bıraktıkları üreticilerin ürünlerinin fiyatlarını olabildiğince düşürerek satın almakta ve yüksek fiyatlara tüketiciye satmaktadırlar. Oysa alternatif kamusal alanda sütün dağıtımında süpermarketler gücünü korumasına rağmen belediye ve kooperatif, üretici ve tüketici arasındaki arac1 sayısını mümkün olduğunca asgariye indirmek amacıyla çeşitli çalışmalar yürütmektedir. İzmir'de kurulacak halk sütü büfeleri, kooperatif ürünlerinin satıldığı mağaza ve bayiiler yanında ihtiyacı olan ailelere araçlarla evlere ücretsiz süt dağıtımı gibi çeşitli alternatif dağıtım kanalları oluşturulmaktadır. Bu şekilde üretici ve tüketici arasında doğrudan bir köprü oluşturularak arac1ların devreden çıkartılması ve sütün kentteki tüketiciye doğrudan daha ucuza ulaşması hedeflenmektedir. Ayrıca ekonomik olarak zor durumda olan aileler ilgili makamlara başvuru yaparak belediye ve kooperatifin birlikte üstlendiği, adrese düzenli ücretsiz süt dağıtımı olanağından yararlanabilmektedirler. Ucuz hatta ücretsiz ve güvenli gıdanın halkın bütün kesimlerine ulaşabilmesi belediye ve kooperatif arasındaki işbirliğine dayalı modelin en önemli ayaklarindan biridir.

\section{Sonuç ve Politika Önerileri}

İzmir Büyükşehir Belediyesi, Tire Süt Kooperatifi, üretici ortaklar ve halkın çeşitli kesimlerinin dahil olduğu alternatif kamusallık yönetim, üretim, dağıtım ve pazarlama, gıda güvenliği gibi çeşitli düzeylerde eşitlik, işbirliği ve güven ilkeleriyle örülmektedir. Üretim ve tüketim süreçlerinin kooperatif ve belediye gibi demokratik denetim ve kontrollere tabi aktörler tarafından düzenlenmesi, tüketicinin ve ekonomik gücü olmayan halk kesimlerinin sağlıklı, güvenli gidaya erişimi, toprak ve hayvanlar üzerinde şirketlerin yarattığı kârlılık baskısının azalması üretilen kamusallığın çeşitli çıktıları olarak saptamak mümkündür.

Kooperatif ve belediye arasındaki işbirliği ve hiyerarşik olmayan ilişkiler sayesinde süt piyasasında üreticinin üretimle bağını güçlendirebildiği ve ürününe sahip çıkabildiği bir alan yaratılabildiği görülmektedir. Ayrıca üretici ürettiği süte yabancılaşmamakta, sütün İzmir'de dar gelirli bir aile tarafından tüketildiğini bilmektedir. Kârlılığın artırılması tek amaç olmayınca kooperatif üretim maliyetlerinde artışlar yaratmasına rağmen sağlıklı, güvenli gıda üretimi altyapısı için geniş bir kaynak ayırabilmektedir. Temel bir besin olan sütün İzmir'de halkın geniş kesimlerine ulaştırılması ve aradaki büyük marketlerden oluşan aracılara bağımlılığın en aza indirilmesi yönünde çalışmalar da dağıtım ve pazarlama sürecinin eşitlikçi ve yatay bir zeminde oluşmasını sağlamaktadır. Çeşitli sermaye grupları ve aracıların etkinliğinin sınırlandırılarak sütün belirli bir fiyat ve kalite standardıyla düzenli olarak piyasaya arz edilmesi gida krizi risklerinin ve spekülasyonlarının önlenmesinde de büyük önem taşımaktadır. Buraya kadar üzerinde durulduğu gibi hayatın her alanında sistemin ürettiğ sorunlara karşı belediye işbirliğiyle güçlendirilmiş bir kooperatifleşme deneyiminin çözüm üretme kapasitesinin oldukça yükseldiği görülmektedir. Ayrıca bütün bu süreçlerin yerelde, Tire'nin üreticilerini ve İzmir halkını temsil eden kurum ve örgütler tarafından organize edilmesinin de ayrı bir değeri vardır.

Yapılan görüşmelerde bazı üretici ortakların son yıllarda hızlı bir büyüme sürecine girdiği, aile emeğine dayalı küçük üretici olmaktan çıkıp ücretli emek 
ağırlıklı üretimi sürdüren işletmelere dönüştüğü saptanmıştır. Kooperatif tipi örgütlenmeler şirket tipi örgütlenmelerinden farklı olarak tek başına üretim, verimlilik artışları yakalamanın ötesine geçip bu artışların ne pahasına yakalandığını, çalışan işçilerin çalışma ve yaşam koşullarında iyileşme olup olmadığını dikkate almak zorunda olan örgütlenmelerdir. Bu nedenle kooperatif bünyesinde yer alan ortakların işletmelerinde çalışan ücretli emeğin boyutları, ücret, sigorta ve güvence durumu üzerine ayrıntılı bir çalışma yapılmalıdır. Mülk sahibi ortakların çiftliklerinde çalışan işçiler için ücret, sigorta ve diğer sosyal haklar ve yaşam koşulları bakımından asgari koşulların sağlanıp sağlamadığı kooperatifin görev kapsamında olmalıdır.

Özellikle son yıllarda tarım sektörünün güvencesiz, sigortasız ve düşük ücretlerle çalıştırmaya dayalı istihdam biçiminin oldukça yaygın olduğu sektörlerden biri olduğu düşünülürse, kooperatif yönetimi istihdam rejiminde yapacağ 1 iyileştirmelerle örnek deneyim olma niteliğini pekiştirecektir.

Türkiye'de son yıllarda tarımsal üretim yoğun olarak şirketler ve diğer sermaye gruplarının etkinlik alanı haline gelirken İzmir yerelinde, üreticiler ve kentteki tüketicileri temsil eden belediye ve kooperatif arasındaki işbirliğine dayanan, tabandan desteklenen alternatif bir seçenek yaratılmıştır. Tire Süt Kooperatifi Türkiye genelinde kooperatiflerin verimsiz ve hantal çalışan kurumlar olduğu, üye ortaklar yerine yöneticilere ve siyasilere çıkar sağladığı gibi yaygın bir olumsuz algı ve imajın kırılmasında örnek bir kooperatif haline gelmiştir. Ayrıca son yıllarda tarımda yaşanan çok yönlü dönüşümün beraberinde getirdiği sorunlar özellikle gıda tüketim boyutuyla yoğun olarak tartışılmasına rağmen bu sorunların nasıl çözülebileceği, ne tip alternatifler üretilmesi gerektiği gibi sorular büyük ölçüde yanıtsız bırakılmaktadır.

Bir alternatif olarak değerlendirilen, son yıllarda hızlı bir gelişme sürecine giren organik tarım sadece yüksek gelir grubuna hitap eden bir sektör haline gelmiştir. Oysa Tire Süt Kooperatifi hem üreticinin ürettiği üründe söz sahibi olabilmesi hem de üretilen güvenli gıdanın halkın geniş kesimlerine ulaştırılabilmesi anlamında Türkiye için bir örnek niteliği taşımaktadır. Bu örneğin mimarlarından İzmir Büyükşehir Belediyesi ve Tire Süt Kooperatifi ürettikleri alternatif seçeneğin yaygınlaşması amacıyla mümkün olduğunca diğer belediyeler ve kooperatiflerle işbirliğine girmelidir. Tire'de "birlik" olma ilkesiyle örülen deneyimin sağladığı imkânlar belirli bir il ve ilçenin ayrıcalığı olarak kalmamalı, bu olumlu örneğin mümkün olduğunca tanıtılması ve yaygınlaştırılması vizyonuyla hareket edilmelidir.

\section{Kaynakça}

Akçay, Ümit. "Ekonomik Demokrasi Ama Nasıl? Planlama Yeniden”. Başlangıç, 13 Mart 2015, http://baslangicdergi.org/ekonomik-demokrasi-ama-nasil-planmala-yeniden, erişim tarihi 22 Mayıs 2017.

Aruoba, Çelik. “Tarımsal Kalkınmada Kredi Kooperatiflerin Önemi Üzerine Bazı Düşünceler". Siyasal Bilgiler Fakültesi Dergisi 26, no. 2 (1971): 107-135.

Aydın, Zülküf. "Neo-Liberal Transformation of Turkish Agriculture". Journal of Agrarian Change 10, no. 2 (2010): 149-187.

Ballı, Ergül. “Türkiye'de Tarımsal Kooperatifçiliğin Gelişimi ve Fiskobirlik: Tarihsel Bir Değerlendirme". Türkiye Cumhuriyeti'nin Ekonomik ve Sosyal Tarihi Uluslararası Sempozyumu'nda sunulan bildiri, Atatürk Araştırma Merkezi, İzmir, 26-28 Kasım 2015.

Boratav, Korkut. Tarımsal Yapılar ve Kapitalizm. Ankara: İmge Kitabevi, 2004.

Brass, Tom. "How Agrarian Cooperatives Fail: Lessons From 1970s Peru". The Journal of Peasant Studies 34, no. 2 (2007): 240-287. 
Çetin, Hakkı. "Kamu Ekonomisi Yönünden Tarım Satış Kooperatifleri Birliklerinin Fonksiyonları". Vergi Sorunları Dergisi 297 (2013): 155-163.

Dinçer, Nabi. "Türkiye'de Kooperatifçilik". Cumhuriyet Dönemi Türkiye Ansiklopedisi, cilt 9 içinde 1274. İstanbul: İletişim Yayınları, 1985.

Fındıkoğlu, Ziyaeddin. Kooperasyon Sosyolojisi: Nazari ve Tatbiki Kooperatifçilik Denemesi. İstanbul: İstanbul Üniversitesi Yayınları, 1974.

İnalcık, Halil. “Çiftliklerin Doğuşu: Devlet, Toprak Sahipleri ve Kiracılar". Osmanlı Toprak Mülkiyeti ve Ticari Tarım içinde, derleyen Çağlar Keyder ve Faruk Tabak, 15-35. İstanbul: Tarih Vakfı Yurt Yayınları, 2010.

Kessler, Gerdhard. Kooperatifçilik. Çeviren Ziyaeddin Fındıkoğlu. İstanbul: İstanbul Üniversitesi Yayınları, 1940.

Keyder, Çağlar ve Zafer Yenal. “Türkiye’de Tarım ve Gıda Üretiminin Yeniden Yapılanması ve Uluslararasılaşması". Bildiğimiz Tarımın Sonu: Küresel İktidar ve Köylülük içinde 103-136. İstanbul: İletişim Yayınları, 2013.

"Kırsal Kalkınmada İzmir Modeli", 4 Mevsim 5, no. 17 (2016): 22-24.

Lenin, V. I. Tarımda Kapitalizm. Çeviren Serpil Güvenç. Ankara: Sol Yayınları, 1996.

Marks, Karl ve Friedrich Engels. Gotha ve Erfurt Programlarının Eleştirisi. Ankara: Eriş Yayınlar1, 2004.

Marx, Karl. Kapital, üçüncü cilt. Çeviren Alaattin Bilgi. Ankara: Sol Yayınları, 2004.

Oral, Necdet, der. Türkiye'de Tarımın Ekonomi-Politiği 1923-2013. Ankara: Notabene Yayınları, 2013.

Oral, Necdet. Türkiye Tarımında Kapitalizm ve Sınıflar. Ankara: TMMOB Yayınları, 2006.

Outhwaite, William, der. Modern Toplumsal Düşünce Sözlüğ̈̈̈. İstanbul: İletişim Yayınları, 2008.

Özbek, Meral, der. Kamusal Alan: Politik Kamusal Alan ve Kolektif Yaratıcılık. İstanbul: Hil Yayın, 2002.

Özden, Fatih. "Doğadan Tüketiciye Tarımda Kapitalist Tahakkümün Kimi Görünümleri, Yabancılaşma ve Alternatifler Üzerine". Praksis 43 (2017): 741-765.

Pahnke, Anthony. "Institutionalizing Economies of Opposition: Explaining and Evaluating the Success of the MST's Cooperatives and Agroecological Repeasantization". The Journal of Peasant Studies 42, no. 6 (2015): 1087-1107.

Proudhon, P. J. General Idea of The Revolution In The Nineteenth Century. Çeviren John Beverley Robinson. New York: Haskell House Publishers Ltd., 1969.

Sina, Zeynep ve Serap Soyer. "Sosyolojik Açıdan Kooperatifçilik Teorisinin Niteliğine İlişkin Düşünceler". Amme İdaresi Dergisi 31, no. 3 (1998): 103-117.

Sklair, Leslie. Globalization: Capitalism and Its Alternatives. Oxford: Oxford University Press, 2002.

Sulemezov, Stoyan. Lenin Kooperatif Planı ve Bulgaristan Kooperatif Hareketi. Ankara: Bilim ve Sosyalizm Yayınları, 1976.

Şahin, Güven ve Nuran Taşlıgil. "Kolektif İşletme Tiplerine Tipik Bir Örnek: Kibbutzlar". Adıyaman Üniversitesi Sosyal Bilimler Enstitüsü Dergisi 9 (2012): 213-229.

T.C. Gümrük ve Ticaret Bakanlığı Kooperatifçilik Genel Müdürlüğü, “Türkiye Kooperatifçilik Stratejisi ve Eylem Planı 2012-2016", http://www.gtb.gov.tr.

Tekeli, İlhan. İzmir İli/Kenti İçin Bir Tarımsal Gelişme ve Yerleşme Stratejisi. İzmir: İzmir Akdeniz Akademisi, 2017.

Thompson, E. P. İngiliz İşçi Sınıfının Oluşumu. Çeviren Uygur Kocabaşoğlu. İstanbul: İletişim Yayınevi, 2006.

Tire Süt Kooperatifi Tanıtım Kitapçı̆̆ı. Tire, 2017.

Tugay, Ertuğrul. “IBB'nin Tarıma ve Kırsal Kalkınmaya Yönelik Çalışmaları Yayınlanmamış Bilgi Notu”. İBB Tarımsal Desteklemeler Daire Başkanlığı, 2016.

Uzgören, Nusret. Atatürk Kooperatifçilik ve Türk Kooperatif̧̧ilik Kurumu. Ankara: Türk Kooperatifçilik Kurumu Yayınları, 1983.

Yasa, İbrahim. "Kibbutz'un Toplumsal İdeolojisi ve Yapısı". Ankara Üniversitesi Siyasal Bilgiler Fakültesi Dergisi 27 (1972): 9-15.

Yıldırım, Uygar Dursun. Türkiye Tarımında Yapısal Dönüşüm ve Mevsimlik Tarım İşçileri: Sakarya Örneği. İstanbul: Sav Yayınları, 2015.

Yılmaz, Koray R. “Alternatif Kamusalın Politik Ekonomisi: Teorik Bir Tartışma ‘Genel Olarak Sermaye'den 'Genel Olarak Birliğe'”, Praksis 30-31 (2012-2013): 257-274. 